\title{
WE HAVE INTIMATED TOO MUCH OF OURSELVES TO THIS CITY
}

\author{
Oscar Tantoco Serquiña, Jr. \\ University of the Philippines Diliman \\ ojserquina@gmail.com
}

\section{About the Author}

While pursuing a Master of Arts degree in Comparative Literature, Oscar Tantoco Serquiña, Jr. serves on the faculty of the Department of Speech Communication and Theatre Arts at the University of the Philippines in Diliman. 


\section{POINTS OF VIEW}

I.

I took a picture of the river.

I want you to look at the other

compositions surrounding it:

shabby houses, sprawling dry hills,

and in the center, a boy

underneath the murky current, settled

like a $\log$.

Look at him closely: eye sockets like caves,

a crack on his head like a zip line.

Now tell me his story. Tell me what I need to know.

\section{II.}

Let's say there is a boy who passes by the river every sundown. Around him, portraits of hope. Above, the cinnamon sky.

Let's say the boy is the central news of the town. The town a mute chronicler of this event.

The day and its speculations. The night and its persistent prayers.

Let's say the boy is in search of home. Let's say he has found one and permanently stays there.

\section{III.}

What does it mean when we say: Is the boy's story about to end?

Or when we declare: The boy's story is at the end of the line. 
IV.

Given the images blurring in the water.

Given the suspicions thickening in the air.

Given the palpable presence of regret.

Given the grainy portrait hanging on the wall.

Given the gestures that precede night time.

Given the rhetoric of letting go.

Given the transportation of a noun into verb into noun.

Given the word stay as wish and order.

Given the perils of metaphor.

Given the varieties of there, there, there.

Given the narratives that begin with Once there was a boy.

V.

Each day the neighbors talk in versions of optimism.

There is a confidence that insists and recurs.

That growing faith in the fate of the boy.

But it has been a year since.

And now the nights are empty. There are other stories to tell.

Like the texture of drying fields in the summer, or the soreness

That creeps around wounds of a child.

The only thing left is imagination.

Still a secret. Still a life. 
VI.

When we talk about the boy we are probing the absence of clarity. We are trying to generate beginnings, one after another. Close your eyes, the elders would say. And you'll see him, sleeping in the woods, his chest ripped open, his mouth shaped by the last word that had escaped it. There are witnesses to this plot we hardly let go: the countenance of stones, the movements of minnows, the wind that echoes our hopes for the disappeared. Somewhere, a pack of kids jumps into the river and glistens under the toasting sun. We tremble in fear, in broad daylight, at dusk time, again and again. We look at the sky with devotion and request. We open our mouths and utter the alphabet for saints. How does a story progress from here?

\section{ATTACHMENTS}

In the marketplace near the church, where fruits are sold

and not bought, or where a kid is left

and not sought, we hear a woman seller deliver

the litany of commerce

like a eulogy,

that when she places her hand on the roundness of an apple

all we can think of is the image

of a stillborn child. And from this view

we further begin 
the recounting of what resides here:

blood on the pavement

affirming what might happen

again happened,

untended underbrush telling

of failures we fail

to admit with grace.

Yet we choose to say nothing

to each other's faces

in the day's regular haze

of events. Because we rather keep

the sum of our losses

in prayers. In this city,

things do not fall apart

but together,

so we hold on

to what has yet to collapse.

There is a word

to all that we keep whole

amidst the wreckages

we meet and may foretell:

perhaps acceptance, or endurance, 
or something more

intimate that assembles us

in this landscape

we insist to call ours.

Stay we must, indeed, in the here and now

full of abandonment.

We are hurting no more.

\section{VISITATION}

You come closer to the door and say the word hello.

But there's no one to answer, the house a sheer structure of dereliction. You vaguely recall this scene: a belt

$$
\text { breaking the seams of tension, a fist }
$$

pounding the floor, footsteps, a message

the day after. It's been years since

and you are convinced of returning. The self now prepared, stale facts dispelled, intense pride compelled

to die down. Hello, you again say, excitement

depleting in every silence, the rebound

of sound in empty space. Where are they? Around you:

daylight, the tarnished beauty

of the once known. And so this must be clear now: between you

and this house stands bereavement. Stinging agony

in the body, memory that waits to be

unhinged. How can such waiting be summarized to this? 
Just a visit, never a return. The horizon points

to many directions from here: cities you've been to, families you have owned.

You have endured enough.

There's a place to go, there's a decision to be made. 